\title{
GGH Gene
}

National Cancer Institute

\section{Source}

National Cancer Institute. GGH Gene. NCI Thesaurus. Code C103943.

This gene is involved in polyg lutamate hydrolysis. 